\title{
An evaluation of EDTA compounds for iron fortification of cereal-based foods
}

\author{
Richard F. Hurrell ${ }^{1 *}$, Manju B. Reddy ${ }^{2}$, Joseph Burri ${ }^{3}$ and James D. Cook ${ }^{4}$ \\ ${ }^{1}$ Nestec Ltd, Nestlé Research Centre, Lausanne, Switzerland \\ ${ }^{2}$ Iowa State University, Department of Food Science and Human Nutrition, Ames, IA, USA \\ ${ }^{3}$ Nestlé Product Technology Centre, Orbe, Switzerland \\ ${ }^{4}$ Kansas University Medical Center, Kansas City, KS, USA
}

(Received 20 October 1999 - Revised 20 April 2000 - Accepted 9 May 2000)

\begin{abstract}
Fe absorption was measured in adult human subjects consuming different cereal foods fortified with radiolabelled $\mathrm{FeSO}_{4}$, ferrous fumarate or $\mathrm{NaFeEDTA}$, or with radiolabelled $\mathrm{FeSO}_{4}$ or ferric pyrophosphate in combination with different concentrations of $\mathrm{Na}_{2}$ EDTA. Mean Fe absorption from wheat, wheat-soyabean and quinoa (Chenopodium quinoa) infant cereals fortified with $\mathrm{FeSO}_{4}$ or ferrous fumarate ranged from 0.6 to $2.2 \%$. For each infant cereal, mean Fe absorption from ferrous fumarate was similar to that from $\mathrm{FeSO}_{4}$ (absorption ratio 0.91-1.28). Mean $\mathrm{Fe}$ absorption from $\mathrm{FeSO}_{4}$-fortified bread rolls was $1.0 \%$ when made from high-extraction wheat flour and $5.7 \%$ when made from low-extraction wheat flour. Fe absorption from infant cereals and bread rolls fortified with NaFeEDTA was 1.9-3.9 times greater than when the same product was fortified with $\mathrm{FeSO}_{4}$. Both high phytate content and consumption of tea decreased $\mathrm{Fe}$ absorption from the NaFeEDTA-fortified rolls. When $\mathrm{Na}_{2}$ EDTA up to a 1:1 molar ratio (EDTA:Fe) was added to $\mathrm{FeSO}_{4}$-fortified wheat cereal and wheat-soyabean cereal mean $\mathrm{Fe}$ absorption from the wheat cereal increased from $1.0 \%$ to a maximum of $5.7 \%$ at a molar ratio of $0.67: 1$, and from the wheat-soyabean cereal from $0.7 \%$ to a maximum of $2.9 \%$ at a molar ratio of 1:1. Adding $\mathrm{Na}_{2}$ EDTA to ferric pyrophosphate-fortified wheat cereal did not significantly increase absorption $(P>0.05)$. We conclude that $\mathrm{Fe}$ absorption is higher from cereal foods fortified with NaFeEDTA than when fortified with $\mathrm{FeSO}_{4}$ or ferrous fumarate, and that $\mathrm{Na}_{2}$ EDTA can be added to cereal foods to enhance absorption of soluble Fe-fortification compounds such as $\mathrm{FeSO}_{4}$.
\end{abstract}

Iron fortification: Iron absorption: EDTA: Cereal-based foods

Fe deficiency is a major cause of anaemia in infants, children, and women of reproductive age, especially in the poorer countries of the developing world, and to a lesser extent in the more industrialised nations, (DeMaeyer \& Adiels-Tegman, 1985). Fe-deficiency anaemia can decrease mental and psychomotor development in children (Lozoff et al. 1991), increase both morbidity and mortality of mother and child at childbirth, decrease work performance, and decrease resistance to infection (Scrimshaw, 1984; Hercberg et al. 1987). One strategy to prevent Fe-deficiency anaemia is to fortify food products with Fe; cereal-based foods are a popular choice as vehicles for $\mathrm{Fe}$ fortification. Cereal flours, such as wheat and maize, are fortified with $\mathrm{Fe}$ to supplement the general population, whereas Fe-fortified infant cereals and breakfast cereals are targeted more specifically at infants, children and adolescents (Hurrell, 1997).

Cereal-based foods, however, are particularly difficult to fortify with $\mathrm{Fe}$, since they contain significant quantities of phytic acid, a potent inhibitor of Fe absorption (Hallberg et al. 1987; Hurrell et al. 1992). In addition, when soluble Fe compounds of high relative bioavailability, such as $\mathrm{FeSO}_{4}$ are added, cereal foods readily become rancid during storage due to $\mathrm{Fe}$-catalysed fat oxidation reactions (Hurrell et al. 1989). As a result of these potential organoleptic problems, many cereal-based foods are fortified with elemental Fe powders which, at best, are only about half as well absorbed as $\mathrm{FeSO}_{4}$ (Hurrell, 1997).

\footnotetext{
* Corresponding author: Dr Richard Hurrell, present address Laboratory for Human Nutrition, ETHZ, PO Box 474, CH-8803 Rüschlikon, Switzerland, fax +41 1704 5710, email richard.hurrell@ilw.agrl.ethz.ch
} 
Some infant cereals are now fortified with ferrous fumarate, which is reported to have equivalent absorption to $\mathrm{FeSO}_{4}$ with less sensory problems (Hurrell et al. 1989).

The most effective way to overcome the inhibitory effect of phytic acid and to promote absorption of fortification $\mathrm{Fe}$ is to add ascorbic acid (Forbes et al. 1989; Davidsson et al. 1994a). Without the addition of ascorbic acid to Fefortified cereals, Fe absorption may be as low as $1 \%$, even when $\mathrm{FeSO}_{4}$ is added (Derman et al. 1980; Cook et al. 1997). The problem with ascorbic acid is that it is readily degraded during food processing (Hallberg et al. 1989) and during storage if the food is not in a special package designed to keep out $\mathrm{O}_{2}$ and humidity. Although ascorbic acid is often added to Fe-fortified cereals as an absorption enhancer, it has not been added to cereal flours.

An alternative Fe compound that appears highly suitable for the fortification of cereal-based foods is NaFeEDTA. This compound has been reported to be about two to four times better absorbed than $\mathrm{FeSO}_{4}$ from a variety of meals containing cereals and legumes (Layrisse et al. 1977; Martinez-Torres et al. 1979; MacPhail et al. 1981). Furthermore, it does not promote fat oxidation in stored wheat flour (Hurrell, 1997), and it is stable during processing and storage. It would also seem possible to add the EDTA moiety alone as an absorption enhancer in combination with other Fe compounds. When El-Guindi et al. (1988) added equimolar quantities of $\mathrm{FeSO}_{4}$ and $\mathrm{Na}_{2}$ EDTA to Egyptian bread, Fe absorption increased from $2.1 \%$ to $5.3 \%$. More recently, MacPhail et al. (1994) reported a 3-fold increase in $\mathrm{Fe}$ absorption from a $\mathrm{FeSO}_{4}$ fortified rice meal when $\mathrm{Na}_{2}$ EDTA was added at a EDTA:Fe molar ratio of $0 \cdot 5: 1$, compared with a 2 -fold increase at a molar ratio of $1: 1$.

In the present study, we have used a radio-Fe technique to measure $\mathrm{Fe}$ absorption by adult human subjects from a selection of infant cereals and wheat bread rolls fortified with ${ }^{59} \mathrm{FeSO}_{4},\left[{ }^{55} \mathrm{Fe}\right]$ ferrous fumarate or $\mathrm{Na}^{55} \mathrm{FeEDTA}$. In addition, we have investigated the absorption-enhancing effect of different concentrations of $\mathrm{Na}_{2}$ EDTA added to ${ }^{59} \mathrm{FeSO}_{4}$ and $\left[{ }^{55} \mathrm{Fe}\right]$ ferric pyrophosphate-fortified wheat infant cereal and to ${ }^{59} \mathrm{FeSO}_{4}$-fortified wheat-soyabean infant cereal.

\section{Subjects, methods and materials}

\section{Subjects}

Fe absorption was measured in eighty-four volunteer subjects aged 18-40 years. The total group included thirty-six males and forty-eight females. All subjects were in good health and denied a history of disorders known to influence the gastrointestinal absorption of Fe. Serum ferritin concentrations ranged from 6 to $668 \mu \mathrm{g} / \mathrm{l}$, indicating a wide variation in Fe status. Fifteen of the subjects, one male and fourteen females, were $\mathrm{Fe}$ deficient as defined by a serum ferritin concentration $<12 \mu \mathrm{g} / \mathrm{l}$. Written informed consent was obtained from each volunteer before the investigation, and all experimental procedures were approved by the Human Subjects Committee at the University of Kansas Medical Center. Subjects were allocated to the studies in the order which they volunteered. There was no randomisation by gender or Fe status.

\section{Iron absorption measurements}

Nine Fe absorption studies were carried out, during which three to four separate Fe absorption measurements were performed in each of seven to ten subjects by using radioFe tracers administered sequentially. All meals were administered between 07.00 and 09.00 hours after an overnight fast and water only was allowed for $3 \mathrm{~h}$. The test meals were fed with labelled $\mathrm{Fe}$ compounds providing either $37 \mathrm{kBq}{ }^{59} \mathrm{Fe}$ or $74 \mathrm{kBq}{ }^{55} \mathrm{Fe}$, and Fe absorption was measured based on erythrocyte enrichment as previously described (Cook et al. 1972).

On the day preceding administration of the first test meal, $30 \mathrm{ml}$ blood was collected from each subject in an EDTA-treated tube for measurement of packed cell volume, serum ferritin (Flowers et al. 1986) and background radioactivity. Meals A (labelled with ${ }^{55} \mathrm{Fe}$ ) and $\mathrm{B}$ (labelled with ${ }^{59} \mathrm{Fe}$ ) were fed on days 2 and 3 of the study respectively. At $14 \mathrm{~d}$ after administration of meal B (day 17), $30 \mathrm{ml}$ blood was drawn for the measurement of incorporated erythrocyte radioactivity. In studies nos. 1-5, 7 and 8 , test meals $\mathrm{C}$ and $\mathrm{D}$ tagged with separate radio-Fe labels were fed on days 17 and 18 respectively, and a final blood sample was obtained on day 32 to determine the increase in erythrocyte radioactivity. In study no. 6 , only meal $\mathrm{C}$ was fed; a final blood sample was collected on day 31. Measurements of blood radioactivity were performed on duplicate $10 \mathrm{ml}$ samples of whole untreated blood by a modification of the method of Eakins \& Brown (1966). Briefly, after digesting whole blood in $\mathrm{HNO}_{3}, \mathrm{Fe}$ is precipitated twice with $\mathrm{NH}_{4} \mathrm{OH}$ and redissolved in $\mathrm{H}_{3} \mathrm{PO}_{4}$ before finally precipitating with $\mathrm{NH}_{4} \mathrm{Cl}$ and ethanol and suspending the precipitate in a gel with a scintillation fluor for counting (Bothwell et al. 1979). Percentage absorption was calculated on the basis of blood volume estimated from height and weight (Wennesland et al. 1959; Brown et al. 1962) and an assumed erythrocyte incorporation of $80 \%$ (Hosein et al. 1967).

\section{Radioactive iron compounds}

The Fe fortification compounds NaFeEDTA, ferrous fumarate and ferric pyrophosphate were labelled with ${ }^{55} \mathrm{Fe}$. They were synthesised in $10 \mathrm{~g}$ batches using a scaleddown version of the normal manufacturing procedures ( Dr Paul Lohman Co., Emmerthal, Germany). The radioactive Fe compounds were in crystalline form and had similar appearance, particle size and solubility in dilute $\mathrm{HCl}$ to their commercial counterparts. The measured Fe content of $\mathrm{Na}^{55}$ FeEDTA was $16.2 \%$ and it contained $15.9 \mathrm{kBq} / \mathrm{mg}$ $\mathrm{Fe}$. The measured $\mathrm{Fe}$ content of $\left[{ }^{55} \mathrm{Fe}\right]$ ferrous fumarate was $32.2 \%$ and it contained $20.4 \mathrm{kBq} / \mathrm{mg}$ Fe. The measured $\mathrm{Fe}$ content of $\left[{ }^{55} \mathrm{Fe}\right]$ ferric pyrophosphate was $28 \%$ and it contained $23.8 \mathrm{kBq} / \mathrm{mg}$ Fe. Non-radioactive Fe compounds were provided by the same manufacturer. 
Table 1. Iron absorption from cereal-based foods fortified with NaFeEDTA, ferrous sulfate and ferrous fumarate in adult human subjects $\dagger$

\begin{tabular}{|c|c|c|c|c|c|c|c|c|c|c|}
\hline \multirow{2}{*}{$\begin{array}{l}\text { Study } \\
\text { no. }\end{array}$} & \multirow[b]{2}{*}{ Study design } & \multicolumn{2}{|c|}{ Serum ferritin $(\mu \mathrm{g} / \mathrm{l})$} & \multirow[b]{2}{*}{ Test meals } & \multicolumn{3}{|c|}{ Fe absorption (\% dose) } & \multicolumn{3}{|c|}{ Absorption ratio§ } \\
\hline & & Mean‡ & Range & & Mean‡ & $-1 \mathrm{SE}$ & $+1 \mathrm{SE}$ & Mean‡ & $-1 \mathrm{SE}$ & $+1 \mathrm{SE}$ \\
\hline \multirow[t]{4}{*}{1} & Wheat infant cereal & 39 & $10-178$ & A Ferrous fumarate & 2.06 & 1.48 & $2 \cdot 88$ & 0.94 & 0.78 & $1 \cdot 13$ \\
\hline & (3 M, $5 \mathrm{~F}, 22$ years) & & & B Unfortified & 3.90 & $2 \cdot 60$ & $5 \cdot 87$ & $1.78^{*}$ & 1.41 & $2 \cdot 23$ \\
\hline & & & & C NaFeEDTA & $5 \cdot 23$ & 4.02 & 6.79 & $2 \cdot 37^{\star \star \star}$ & $2 \cdot 19$ & 2.58 \\
\hline & & & & $\mathrm{D} \mathrm{FeSO}_{4}$ & $2 \cdot 20$ & 1.66 & $2 \cdot 91$ & - & - & - \\
\hline \multirow[t]{4}{*}{2} & Wheat-soy infant cereal & 42 & $13-104$ & A Ferrous fumarate & 0.93 & 0.62 & 1.40 & $1 \cdot 28$ & 0.99 & 1.66 \\
\hline & (4 M, $5 \mathrm{~F}, 27$ years) & & & B Unfortified & 1.13 & 0.76 & 1.69 & $1.56^{\star}$ & 1.40 & 1.74 \\
\hline & & & & C NaFeEDTA & $2 \cdot 81$ & 1.91 & $4 \cdot 13$ & $3 \cdot 86^{\star \star \star}$ & 3.25 & 4.59 \\
\hline & & & & $\mathrm{D} \mathrm{FeSO}_{4}$ & 0.73 & 0.49 & 1.07 & - & - & - \\
\hline \multirow[t]{4}{*}{3} & Quinoa (chenopodium & 39 & $20-118$ & A Ferrous fumarate & 0.57 & 0.47 & 0.70 & 0.91 & 0.67 & 1.25 \\
\hline & quinoa) infant cereal & & & B Unfortified & 0.67 & 0.47 & 0.96 & 1.07 & 0.86 & 1.35 \\
\hline & (3 M, 4 F, 22 years) & & & C NaFeEDTA & 1.68 & $1 \cdot 25$ & $2 \cdot 25$ & $2 \cdot 60^{\star \star}$ & $2 \cdot 28$ & $3 \cdot 14$ \\
\hline & & & & $\mathrm{D} \mathrm{FeSO}_{4}$ & 0.63 & 0.42 & 0.94 & - & - & - \\
\hline \multirow[t]{4}{*}{4} & Wheat-soyabean & 41 & $11-114$ & A NaFeEDTA & $3 \cdot 32$ & $2 \cdot 40$ & 4.60 & $3 \cdot 53^{\star \star}$ & 3.00 & 4.01 \\
\hline & infant cereal & & & $\mathrm{B} \mathrm{FeSO}_{4}$ & 0.94 & 0.70 & $1 \cdot 26$ & - & - & - \\
\hline & (4 M, 5 F, 23 years) & & & C NaFeEDTA $\times 3$ & 1.94 & $1 \cdot 60$ & $2 \cdot 34$ & $2 \cdot 70^{\star \star}$ & 1.01 & $4 \cdot 25$ \\
\hline & & & & $\mathrm{D} \mathrm{FeSO}_{4} \times 3$ & 0.72 & 0.50 & 1.04 & - & - & - \\
\hline \multirow[t]{4}{*}{5} & Low-extraction wheat & 54 & $13-668$ & A NaFeEDTA & 11.50 & $8 \cdot 62$ & $15 \cdot 4$ & $2 \cdot 02^{* *}$ & $1 \cdot 72$ & $2 \cdot 38$ \\
\hline & bread roll & & & $\mathrm{B} \mathrm{FeSO}_{4}$ & $5 \cdot 70$ & $4 \cdot 30$ & 7.55 & - & - & - \\
\hline & (5 M, $5 \mathrm{~F}, 25$ years) & & & C NaFeEDTA, tea & 1.86 & $1 \cdot 30$ & $2 \cdot 65$ & $1 \cdot 81^{\star \star}$ & 1.57 & $2 \cdot 10$ \\
\hline & & & & $\mathrm{D} \mathrm{FeSO}_{4}$, tea & 1.03 & 0.69 & $2 \cdot 65$ & - & - & - \\
\hline \multirow[t]{3}{*}{6} & High-extraction heat & 20 & $3-60$ & A Unfortified & $2 \cdot 27$ & 1.58 & $3 \cdot 27$ & $2 \cdot 29^{*}$ & 1.67 & $3 \cdot 14$ \\
\hline & bread roll & & & B NaFeEDTA & 3.91 & $2 \cdot 68$ & 5.69 & $3 \cdot 94^{\star * *}$ & $3 \cdot 28$ & $4 \cdot 74$ \\
\hline & (6 M, $4 \mathrm{~F}, 26$ years) & & & $\mathrm{C} \mathrm{FeSO}_{4}$ & 0.99 & 0.72 & 1.36 & - & - & - \\
\hline
\end{tabular}

$\mathrm{M}$, male; F, female.

Mean values were significantly different from $1:{ }^{\star} P<0.05,{ }^{\star \star} P<0.01,{ }^{\star \star \star} P<0.001$.

† For details of procedures, see p. 904

$\ddagger$ Geometric mean.

$\S$ Absorption from test meal compared with absorption from $\mathrm{FeSO}_{4}$ (studies nos. $1-6$ ), $\mathrm{FeSO}_{4} \times 3$ (study no. 4) or FeSO $\mathrm{plus}_{4}$ tea (study no. 5) test meals.

\section{Cereal-based foods}

Three experimental infant cereals were prepared at the Nestlé Product Technology Centre, Orbe, Switzerland. The wheat-based infant cereal was made from $60 \%$ extraction wheat flour and the quinoa-based infant cereal was made from ground whole sweet quinoa (Chenopodium quinoa) grains (Nestlé Development Centre, Quito, Ecuador). The flours were mixed with sucrose-water $(1: 10, w / v)$ to reach a slurry with about a $40 \%(\mathrm{w} / \mathrm{v}) \mathrm{DM}$. The slurry was cooked by steam injection (about $135^{\circ} \mathrm{C}$ ) and roller-dried. No other ingredients were added. The wheat-soyabeanbased infant cereal was prepared in a similar way, but from a mixture of $60 \%$-extraction wheat flour and soyabeanprotein isolate (approximately 6:1, w/w). The protein content $(\mathrm{N} \times 6.25 ; \%$, w/w $)$ was 12.3 for wheat cereal, 12.9 for quinoa cereal and 17.2 for wheat-soyabean cereal. Phytic acid was measured by a modification of the Makover (1970) method in which Ce replaced $\mathrm{Fe}$ in the precipitation step. Phytic acid (mg/100 g) was 122,763 and 770 respectively for the wheat, quinoa and wheat-soyabean cereals.

Two different bread rolls were prepared and baked in the laboratory. A low-extraction roll was prepared from the same $60 \%$-extraction wheat flour as the wheat infant cereal. Salt, sugar, yeast, water and the radioactive $\mathrm{Fe}$ compounds were added during preparation of the dough. One series of low-extraction wheat rolls was fortified with $\mathrm{Na}^{55} \mathrm{FeEDTA}$ and the other with ${ }^{59} \mathrm{FeSO}_{4}$. Each roll contained $35 \mathrm{~g}$ wheat flour, $2.15 \mathrm{mg} \mathrm{Fe}$ and either $55.5 \mathrm{kBq}{ }^{55} \mathrm{Fe}$ or $18.5 \mathrm{kBq}{ }^{59} \mathrm{Fe}$. A high-extraction-wheat roll was prepared in a similar way from $80 \%$-extraction wheat flour (Nestlé Product Technology Centre). The rolls were either fortified with $\mathrm{Na}^{55} \mathrm{FeEDTA}$ or ${ }^{59} \mathrm{FeSO}_{4}$ or were unfortified. Each roll contained $50 \mathrm{~g}$ wheat flour and the Fe-fortified rolls contained $2.5 \mathrm{mg} \mathrm{Fe}$ either as $\mathrm{Na}^{55} \mathrm{FeEDTA}(37 \mathrm{kBq})$ or ${ }^{59} \mathrm{FeSO}_{4}(18.5 \mathrm{kBq})$. Phytic acid was degraded to zero during the preparation of the low-extraction-wheat roll, but was not analysed in the highextraction-wheat roll.

\section{Test meals}

In studies nos. 1-3 (Table 1) Fe absorption was compared in subjects fed the infant cereals either unfortified, or fortified with $\mathrm{NaFeEDTA}$, ferrous fumarate or $\mathrm{FeSO}_{4}$. All test meals contained $50 \mathrm{~g}$ infant cereal, $10 \mathrm{~g}$ sucrose and $0.5 \mathrm{~g}$ salt, and were mixed into a porridge with $300 \mathrm{ml}$ hot water. Non-fat milk powder (Carnation, Los Angeles, CA, USA) was added to the wheat and quinoa cereals to equilibrate the crude protein $(\mathrm{N} \times 6.25)$ to that of the wheat-soyabean cereal. $\mathrm{Na}{ }^{55} \mathrm{Fe}$ EDTA and $\left.{ }^{55} \mathrm{Fe}\right]$ ferrous fumarate were accurately weighed to provide $74 \mathrm{kBq}$ to each subject. The Fe compounds were carefully mixed into the cereal porridge together with the necessary amount of the respective non-radioactive $\mathrm{Fe}$ compound to provide a total of $5 \mathrm{mg}$ fortification $\mathrm{Fe}$ to each subject. $\mathrm{FeSO}_{4}(5 \mathrm{mg})$ was added in a slightly different way. A non-radioactive portion providing $2.5 \mathrm{mg} \mathrm{Fe}$ was carefully mixed into the cereal porridge together with a $1 \mathrm{ml}$ solution containing $2.5 \mathrm{mg} \mathrm{FeSO}$ - providing $37 \mathrm{kBq}{ }^{59} \mathrm{Fe}$ in $0.01 \mathrm{~mol} \mathrm{HCl} / \mathrm{l}$. The radioactive tag was added to the unfortified cereals as a $1 \mathrm{ml}$ solution containing $0.1 \mathrm{mg} \mathrm{Fe}$ as $\mathrm{FeCl}_{3}$ with $37 \mathrm{kBq}$ 
Table 2. Iron absorption from infant cereals fortified with ferrous sulfate and different levels of $\mathrm{Na}_{2} \mathrm{EDTA}$ in adult human subjects $\dagger$

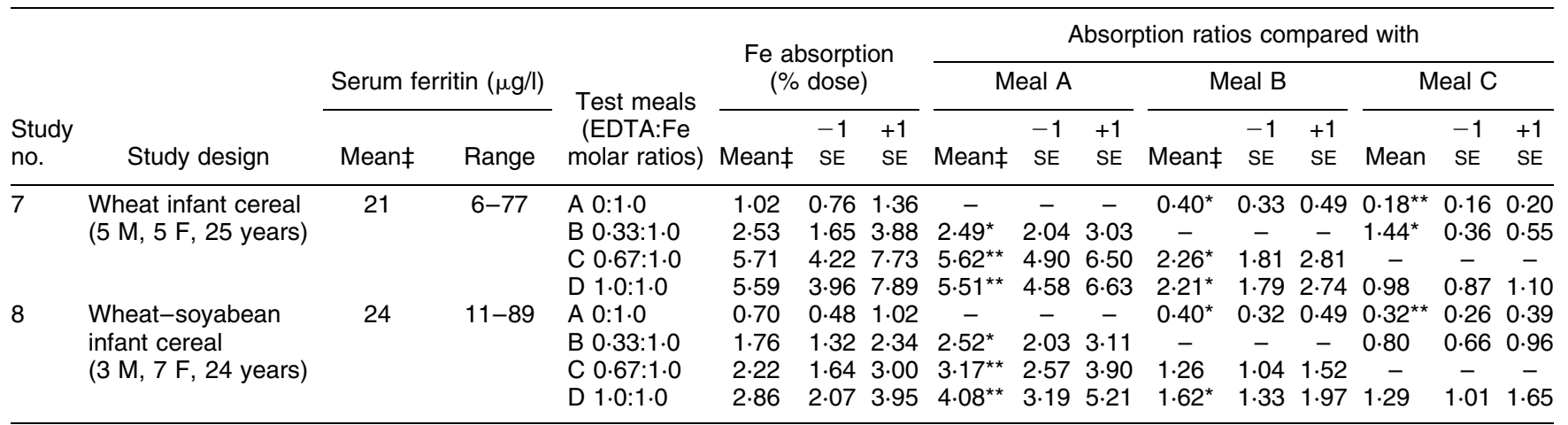

$\mathrm{M}$, male; $\mathrm{F}$, female

Mean values were significantly different from one: ${ }^{\star} P<0.05,{ }^{* *} P<0.01$.

† For details of procedures, see p. 904.

$\ddagger$ Geometric mean.

of ${ }^{59} \mathrm{Fe}$ in $0.01 \mathrm{~mol} \mathrm{HCl} / \mathrm{l}$. In order to ensure complete ingestion of the radio $\mathrm{Fe}$ tag, after consumption of the meal the cereal bowls were carefully rinsed with water and the rinsing water consumed.

In study no. 4 (Table 1) Fe absorption was compared in subjects fed the wheat-soyabean cereal fortified with either 5 or $15 \mathrm{mg} \mathrm{Fe}$ as NaFeEDTA or $\mathrm{FeSO}_{4}$. The test meals were prepared as before. $\mathrm{Na}^{55} \mathrm{FeEDTA}$ was accurately weighed to provide $74 \mathrm{kBq}{ }^{55} \mathrm{Fe}$ to each subject and was carefully mixed into the cereal porridge together with sufficient non-radioactive NaFeEDTA to provide a total of 5 or $15 \mathrm{mg}$ Fe per meal. $\mathrm{FeSO}_{4}$ was added to the cereal as a $1 \mathrm{ml}$ solution containing $2.5 \mathrm{mg} \mathrm{FeSO}$ and $37 \mathrm{kBq}^{59} \mathrm{Fe}$ in $0.01 \mathrm{~mol} \mathrm{HCl} / \mathrm{l}$ together with either 2.5 or $12.5 \mathrm{mg}$ nonradioactive $\mathrm{FeSO}_{4}$ to provide a total of 5 or $15 \mathrm{mg} \mathrm{Fe} \mathrm{per}$ meal.

Study no. 5 (Table 1) compared Fe absorption from subjects fed two low-extraction-wheat rolls fortified with either NaFeEDTA or $\mathrm{FeSO}_{4}$ and fed with or without tea. The rolls were fed with $10 \mathrm{~g}$ butter. For the subjects receiving tea, $3 \mathrm{~g}$ Assam tea purchased locally in Kansas City was infused for $10 \mathrm{~min}$ in $300 \mathrm{ml}$ boiling water, strained and served with $10 \mathrm{~g}$ sugar. Subjects not consuming tea had free access to water. Study no. 6 compared Fe absorption from subjects fed two high-extraction-wheat rolls either unfortified, or fortified with NaFeEDTA or
$\mathrm{FeSO}_{4}$. The rolls were fed with $20 \mathrm{~g}$ butter and $200 \mathrm{ml}$ water.

Studies nos 7 and 8 (Table 2) investigated the influence of different levels of $\mathrm{Na}_{2}$ EDTA (Fisher Scientific, Fair Lawn, $\mathrm{NJ}$, USA) in subjects fed $\mathrm{FeSO}_{4}$-fortified wheat cereal or wheat-soyabean cereal respectively. In study no. 7, each subject received $50 \mathrm{~g}$ wheat cereal, $10 \mathrm{~g}$ sucrose, $0.5 \mathrm{~g}$ salt and $4 \mathrm{mg} \mathrm{Fe}$ as $\mathrm{FeSO}_{4}$ mixed into a porridge with $300 \mathrm{ml}$ hot water. $\mathrm{Na}_{2}$ EDTA and the radio-Fe tracers were mixed into the porridge just before feeding. Meals A, B, C and D contained an EDTA:Fe molar ratio of 0:1, 0.33:1, 0.67:1 and $1: 1$ respectively. The radio-Fe tracers were added in a $1 \mathrm{ml}$ solution containing $0.1 \mathrm{mg} \mathrm{Fe}$ as $\mathrm{FeCl}_{3}$ in $0.01 \mathrm{~mol} \mathrm{HCl} / 1$ (74 $\mathrm{kBq}{ }^{55} \mathrm{Fe}$ to meals A and $\mathrm{C}$ and $37 \mathrm{kBq}{ }^{59} \mathrm{Fe}$ to meals B and D). Study no. 8 was identical to study no. 7 except that wheat-soyabean cereal replaced wheat cereal.

Study no. 9 (Table 3) compared $\mathrm{Fe}$ absorption from wheat infant cereal fortified with $\mathrm{FeSO}_{4}$ or $\left[{ }^{55} \mathrm{Fe}\right]$ ferric pyrophosphate in the presence or absence of $\mathrm{Na}_{2} \mathrm{EDTA}$. Each subject received $50 \mathrm{~g}$ cereal, $10 \mathrm{~g}$ sucrose, $0 \cdot 5 \mathrm{~g}$ salt and $4 \mathrm{mg} \mathrm{Fe}$, either as $\mathrm{FeSO}_{4}$ or $\left[{ }^{55} \mathrm{Fe}\right]$ ferric pyrophosphate $\left(74 \mathrm{kBq}{ }^{55} \mathrm{Fe}\right)$, mixed into a porridge with $300 \mathrm{ml}$ water. $\mathrm{FeSO}_{4}$ was added together with a $1 \mathrm{ml}$ solution containing $0.1 \mathrm{mg} \mathrm{Fe}$ as $\mathrm{FeCl}_{3}$ in $0.01 \mathrm{~mol} \mathrm{HCl} / 1$ providing $37 \mathrm{kBq}$ ${ }^{59} \mathrm{Fe}$. $\mathrm{Na}_{2}$ EDTA was mixed into the porridge before feeding at an EDTA:Fe molar ratio of 1:1.

Table 3. Influence of $\mathrm{Na}_{2} \mathrm{EDTA}$ on iron absorption from ferrous sulfate- and ferric pyrophosphate-fortified wheat infant cereals in adult human subjects†

\begin{tabular}{|c|c|c|c|c|c|c|c|c|c|c|}
\hline \multirow[b]{2}{*}{ Study no. } & \multirow[b]{2}{*}{ Study design } & \multicolumn{2}{|c|}{ Serum ferritin $(\mu \mathrm{g} / \mathrm{l})$} & \multirow[b]{2}{*}{ Test meals } & \multicolumn{3}{|c|}{ Fe absorption (\% dose) } & \multicolumn{3}{|c|}{$\begin{array}{l}\text { Absorption ratios with and } \\
\text { without } \mathrm{Na}_{2} \text { EDTA }\end{array}$} \\
\hline & & Mean‡ & Range & & Mean $\ddagger$ & $-1 \mathrm{SE}$ & $+1 \mathrm{SE}$ & Meanł & $-1 \mathrm{SE}$ & $+1 \mathrm{SE}$ \\
\hline 9 & $\begin{array}{l}\text { Wheat infant cereal } \\
\text { (3 M, } 8 \mathrm{~F}, 24 \text { years) }\end{array}$ & 29 & $9-87$ & $\begin{array}{l}\text { A Ferric pyrophosphate } \\
\text { B FeSO }_{4} \\
\text { C Ferric pyrophosphate } \\
\text { plus } \mathrm{Na}_{2} \mathrm{EDTA} \S \\
\mathrm{D} \mathrm{FeSO}_{4} \text { plus } \mathrm{Na}_{2} \mathrm{EDTA} \S\end{array}$ & $\begin{array}{l}0.26 \\
1.76 \\
0.44 \\
\\
5.93\end{array}$ & $\begin{array}{l}0.16 \\
1.29 \\
0.36 \\
\\
4.66\end{array}$ & $\begin{array}{l}0.42 \\
2.39 \\
0.52 \\
7.54\end{array}$ & $\begin{array}{c}- \\
- \\
1 \cdot 68 \\
3.37^{\star \star \star}\end{array}$ & $\begin{array}{c}- \\
\overline{1} \\
1 \cdot 15 \\
2 \cdot 78\end{array}$ & $\begin{array}{c}- \\
- \\
2 \cdot 47 \\
4 \cdot 10\end{array}$ \\
\hline
\end{tabular}

$\mathrm{M}$, male; F, female.

Mean value was significantly different from $1:{ }^{\star \star \star} P<0.001$

† For details of procedures, see p. 904.

$\ddagger$ Geometric mean.

$\S \mathrm{Na}_{2}$ EDTA added at an EDTA:Fe molar ratio of $1: 1$. 


\section{Statistical analysis}

Percentage absorption values were converted to logarithms for calculating geometric means and for statistical analysis. Original values were recovered by reconverting the results as antilogarithms (Layrisse et al. 1969). Comparison of Fe absorption for any given pair of test meals within each study was made by a paired $t$ test to determine whether the $\log$ absorption ratio differed from zero. The mean absorption ratios for different studies were analysed by ANOVA and significant differences between groups were determined by the Tukey's multiple comparison test (Graphpad Prism, San Diego, CA, USA). In all cases, $P \leq$ 0.05 was taken to indicate a significant difference.

\section{Results}

Fe absorption from ferrous fumarate-, NaFeEDTA-, and $\mathrm{FeSO}_{4}$-fortified infant cereals (studies nos. 1-3) is shown in Table 1. Mean values are given for serum ferritin and percentage $\mathrm{Fe}$ absorption. In most cases, individual $\mathrm{Fe}$ absorption values were highest in those subjects with the lowest serum ferritin values. Mean Fe absorption from infant cereals containing $5 \mathrm{mg}$ fortification Fe ranged from $0.57-5.23 \%$ in the adult subjects. Absorption was higher in subjects fed the wheat cereal than in those fed the wheat-soyabean cereal, and was lowest in subjects fed the quinoa cereal. In all three cereals, ferrous fumarate was absorbed to the same extent as $\mathrm{FeSO}_{4}$. The absorption ratios, which represent the relative absorption or relative bioavailability of ferrous fumarate compared with $\mathrm{FeSO}_{4}$, were $0.91,0.94$ and 1.28 in quinoa, wheat and wheatsoyabean cereals respectively. These values were not significantly different from $1(P>0 \cdot 05)$. Fe absorption from the NaFeEDTA-fortified cereals was 2-4-fold higher than from the $\mathrm{FeSO}_{4}$-fortified cereals. Absorption ratios were $2.37,2.60$ and 3.86 respectively for the wheat, quinoa and wheat-soyabean cereals. These values were all significantly different from $1 \quad(P<0.001)$, but not significantly different from each other $(P>0.05$; ANOVA with Tukey's multiple comparison test). Percentage Fe absorption was higher in subjects fed the unfortified cereals than in subjects fed the $\mathrm{FeSO}_{4}$-fortified wheat or wheat-soyabean cereals (absorption ratios 1.78 and 1.56 respectively; $P<0.05)$ but not the quinoa cereal. Increasing the Fe content in the fortified cereals from 5 to $15 \mathrm{mg}$ per meal slightly decreased $\mathrm{Fe}$ absorption (study no. 4, Table 1) although the absorption enhancing effect of NaFeEDTA compared with $\mathrm{FeSO}_{4}$ was similar at both $\mathrm{Fe}$ concentrations (absorption ratios 3.53 and 2.70 respectively; $P>0.05$ )

In studies nos. 5 and 6 (Table 1), Fe absorption was compared in subjects fed wheat bread rolls fortified with either $\mathrm{NaFeEDTA}$ or $\mathrm{FeSO}_{4}$. Mean Fe absorption ranged from $0.99 \%$ with the $\mathrm{FeSO}_{4}$-fortified high-extractionwheat roll to $11.5 \%$ with the low-extraction-wheat roll fortified with NaFeEDTA. As in the previous studies, Fe absorption was two to four times higher in subjects consuming the rolls fortified with NaFeEDTA than in subjects consuming rolls fortified with $\mathrm{FeSO}_{4}$. With the low-extraction-wheat rolls (study no. 5), the absorption

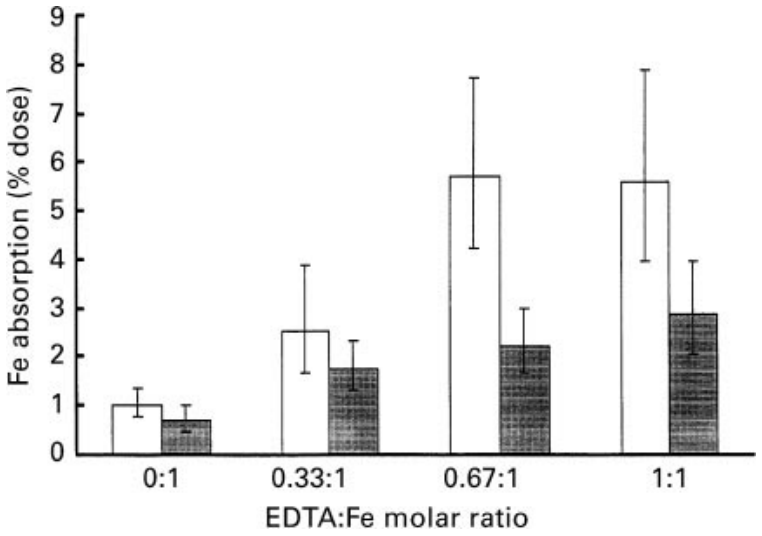

Fig. 1. Iron absorption in adult human subjects from wheat ( $\square$; study no. 7) and wheat-soyabean ( $\square$; study no. 8) infant cereals fortified with ferrous sulfate plus different levels of $\mathrm{Na}_{2}$ EDTA. Values are geometric means with 1 SE represented by vertical bars. For details of procedures, see p. 904 . Adding $\mathrm{Na}_{2}$ EDTA to ferrous sulfatefortified wheat cereal up to an EDTA:Fe molar ratio of 1:1 increased absorption from $1.0 \%$ to $5.7 \%$.

ratio for NaFeEDTA compared with $\mathrm{FeSO}_{4}$ was $2 \cdot 02(P<$ $0.01)$ when consumed with water and $1.81(P<0.01)$ when consumed with tea. With the high-extraction-wheat roll, the absorption ratio was 3.94 when consumed with water $(P<0 \cdot 001)$. Tea consumed with the low-extractionwheat roll significantly decreased the absorption of $\mathrm{FeSO}_{4}$ $(P<0.001)$ and NaFeEDTA $(P<0.0001)$.

In studies nos. 7 and 8 (Table 2; Fig. 1), Fe absorption was compared in subjects fed infant cereals fortified with $\mathrm{FeSO}_{4}$ with increasing amounts of $\mathrm{Na}_{2}$ EDTA as an absorption enhancer. With wheat infant cereal (study no. 7), $\mathrm{Na}_{2}$ EDTA increased $\mathrm{Fe}$ absorption more than 5-fold, from $1.02 \%$ with $\mathrm{FeSO}_{4}$ alone to a maximum of $5.71 \%$ at an EDTA:Fe molar ratio of $0.67: 1$. Increasing the $\mathrm{Na}_{2}$ EDTA content to give an EDTA:Fe molar ratio of $1: 1$ did not further increase Fe absorption. The absorption ratios compared with $\mathrm{FeSO}_{4}$ alone were $2.49(P<0.01)$ at an EDTA:Fe molar ratio of $0.33: 1,5.62(P<0.001)$ at a 0.67:1 molar ratio, and 5.51 $(P<0.001)$ at a $1: 1$ molar ratio. With the wheat-soyabean cereal (study no. 8), Fe absorption was slightly lower and ranged from $0.70 \%$ when fortified with $\mathrm{FeSO}_{4}$ alone to a maximum of $2.86 \%$ when $\mathrm{Na}_{2}$ EDTA was added to give an EDTA:Fe molar ratio of $1: 1$. The absorption ratios compared with $\mathrm{FeSO}_{4}$ alone were $2.52(P<0.01)$ at an EDTA:Fe molar ratio of $0.33: 1,3.17(P<0.001)$ at a $0.67: 1$ molar ratio, and 4.08 $(P<0.001)$ at a $1: 1$ molar ratio. Increasing the EDTA:Fe molar ratio from $0 \cdot 67: 1$ to $1: 1$ increased $F e$ absorption from $2.22 \%$ to $2.86 \%$, although the absorption ratio of 1.29 was not significant $(P>0.05)$.

In study no. 9 (Table 3 ), Fe absorption from the ferric pyrophosphate-fortified cereal was only $0.26 \%$ compared with $1.76 \%$ when fortified with $\mathrm{FeSO}_{4}$. As in study no. 7, adding $\mathrm{Na}_{2}$ EDTA to $\mathrm{FeSO}_{4}$ at an EDTA:Fe molar ratio of $1: 1$ significantly increased $\mathrm{Fe}$ absorption from 1.76 to $5.93 \%$, a 3.4 -fold increase $(P<0.001)$. Adding the same molar ratio of $\mathrm{Na}_{2}$ EDTA to ferric pyrophosphate-fortified cereals resulted in a much lower increase 
in $\mathrm{Fe}$ absorption from 0.26 up to $0.44 \%$, a 1.7 -fold increase $(P>0.05)$.

\section{Discussion}

$\mathrm{FeSO}_{4}$ is an $\mathrm{Fe}$ compound of high relative bioavailability in human subjects. It is usually the benchmark for comparing different $\mathrm{Fe}$ compounds and has been designated a relative bioavailability of 100 (Hurrell, 1997). When $\mathrm{FeSO}_{4}$ is used to fortify cereal foods, however, Fe absorption by human subjects may be unacceptably low due to the natural presence of phytic acid (Cook et al. 1997). In the present studies $\mathrm{Fe}$ absorption from $\mathrm{FeSO}_{4}$ by normal adults was less than $1 \%$ from the high-phytic acid-containing wheatsoyabean and quinoa infant cereals, and from the highextraction-wheat flour (studies nos. 2-4 and 6; Table 1). Fe absorption was only approximately $2 \%$ from the $\mathrm{FeSO}_{4}$ fortified wheat infant cereal made from low-extractionwheat flour, but increased to approximately $6 \%$ when the same flour was baked into a bread roll, presumably due to the degradation of phytic acid during our bread-making process due to the activation of phytases. As would be expected, percentage $\mathrm{Fe}$ absorption increased as the $\mathrm{Fe}$ content of the meals decreased, being highest from the unfortified meals and lowest from the meals containing $15 \mathrm{mg}$ fortification Fe.

Ferrous fumarate is an alternative Fe-fortification compound to $\mathrm{FeSO}_{4}$. It has been reported to have the same relative bioavailability as $\mathrm{FeSO}_{4}$ in adults (Hurrell et al. 1989). Its main advantage is that it causes few, if any, colour and flavour changes in infant cereals (Hurrell et al. 1989), chocolate-drink powders (Hurrell et al. 1991) and maize flour (Layrisse et al. 1996). Unfortunately, it is not protected from phytic acid like $\mathrm{FeSO}_{4}$, and can be poorly absorbed when added to cereal foods. In our studies, Fe absorption ranged from 0.57 to $2.06 \%$ (studies nos. 1-3; Table 1), with an absorption ratio compared with $\mathrm{FeSO}_{4}$ of $0.91-1 \cdot 28$.

NaFeEDTA has been suggested as an ideal Fe fortificant for cereal-based foods, since the EDTA moiety protects Fe from phytic acid (International Nutritional Anemia Consultative Group, 1993) and prevents Fe-catalysed fat oxidation reactions during the storage of cereal flours (Hurrell, 1997). The present studies have shown that NaFeEDTA is a useful additive for a variety of cerealbased foods. Fe absorption was 2-4-fold greater than that from $\mathrm{FeSO}_{4}$, confirming earlier reports on the absorption of Fe from NaFeEDTA-fortified cereal foods. Viteri et al. (1978) have previously reported a 2.5 times greater $\mathrm{Fe}$ absorption by children from a rice-milk cereal when fortified with NaFeEDTA than when fortified with $\mathrm{FeSO}_{4}$, and MacPhail et al. (1981) similarly reported a 2-fold increase in $\mathrm{Fe}$ absorption by adult women from a NaFeEDTA-fortified maize porridge.

Although it is clear that EDTA enhances Fe absorption from foods containing phytic acid, our results suggest that it does not provide complete protection. Fe absorption by volunteers consuming the high-extraction-wheat bread roll fortified with NaFeEDTA (3.91\%; Table 1) was much lower than from the low-extraction-wheat roll $(11.5 \%)$ in which the phytic acid had been completely degraded, even though the serum ferritin levels in the former group of volunteers were lower. Similarly, when fortified with NaFeEDTA, Fe absorption from the high-phytate wheatsoyabean cereal and the quinoa cereal $(2.81$ and $1.68 \%$ respectively; Table 1) was lower than from the low-phytate wheat cereal $(5 \cdot 23 \%)$. Earlier reports that phytic acid had little influence on $\mathrm{Fe}$ absorption from NaFeEDTA were based on the observation that bran added to an aqueous solution of NaFeEDTA did not influence Fe absorption, whereas adding bran to an aqueous solution of $\mathrm{FeSO}_{4}$ greatly reduced $\mathrm{Fe}$ absorption (MacPhail et al. 1985)

The polyphenols from tea are also known to strongly inhibit Fe absorption (Hurrell et al. 1999); consuming tea with the low-extraction-wheat roll fortified with NaFeEDTA reduced $\mathrm{Fe}$ absorption from $11.5 \%$ to $1.86 \%$ (Table 1), thus confirming the earlier report that EDTA cannot completely overcome the inhibitory effect of tea (MacPhail et al. 1981). Although NaFeEDTA does not provide complete protection against phytic acid and polyphenols, in the presence of these inhibitory substances, Fe absorption from cereal foods fortified with NaFeEDTA is 2-4-fold higher than when fortified with Fe compounds such as $\mathrm{FeSO}_{4}$ or ferrous fumarate. NaFeEDTA would thus seem an ideal compound for the fortification of cereal foods, especially as it has recently been approved as a food additive by the Joint FAO/WHO Expert Committee on Food Additives (1999). It should be remembered however that, as with other soluble Fe compounds, NaFeEDTA can cause unwanted colour reactions such as those reported in cereal products with bananas and in chocolate (Hurrell, 1997).

The purpose of the second part of the present study was to evaluate the use of $\mathrm{Na}_{2}$ EDTA as an enhancer of $\mathrm{Fe}$ absorption. The only enhancer of $\mathrm{Fe}$ absorption available to food manufacturers at the present time is ascorbic acid, which has been shown to increase the absorption of soluble $\mathrm{Fe}$ compounds such as $\mathrm{FeSO}_{4}$, less-soluble $\mathrm{Fe}$ compounds such as ferric orthophosphate and elemental Fe (Forbes et al. 1989), and native food $\mathrm{Fe}$ (Layrisse et al. 1977). The advantage of $\mathrm{Na}_{2}$ EDTA over ascorbic acid is that it is stable during food processing and storage, and earlier studies have shown that it can increase the absorption of $\mathrm{FeSO}_{4}$ added to a rice meal (MacPhail et al. 1994).

In the present studies, we have mainly investigated the influence of EDTA on the absorption of $\mathrm{Fe}$ from $\mathrm{FeSO}_{4}$, a soluble $\mathrm{Fe}$ compound. In one study, however, we investigated the influence of $\mathrm{Na}_{2}$ EDTA on $\mathrm{Fe}$ absorption from the insoluble ferric pyrophosphate. The addition of $\mathrm{Na}_{2}$ EDTA to infant cereals fortified with $\mathrm{FeSO}_{4}$ increased $\mathrm{Fe}$ absorption progressively as the EDTA:added $\mathrm{Fe}$ molar ratio was increased. In both the wheat and wheat-soyabean cereals, Fe absorption was increased at EDTA:Fe molar ratios of less than 1:1 (Fig. 1). In the wheat cereal the maximum increase in $\mathrm{Fe}$ absorption occurred at an EDTA:Fe molar ratio of $0 \cdot 67: 1$, supporting the earlier report from MacPhail et al. (1994) that an EDTA:Fe molar ratio of $0.5: 1$ resulted in the maximum increase in $\mathrm{Fe}$ absorption from rice fortified with $\mathrm{FeSO}_{4}$. With the higherphytate-containing wheat-soyabean cereal we found the maximum increase in $\mathrm{Fe}$ absorption at the EDTA:Fe molar ratio of 1:1. 
In contrast to its strong positive influence on $\mathrm{Fe}$ absorption from wheat cereal fortified with $\mathrm{FeSO}_{4}$, we could demonstrate no influence of $\mathrm{Na}_{2}$ EDTA on $\mathrm{Fe}$ absorption from the same cereal fortified with ferric pyrophosphate. Fe absorption from the cereal fortified with ferric pyrophosphate was only $0.26 \%$ compared with $1.76 \%$ with $\mathrm{FeSO}_{4}$ (Table 2). $\mathrm{Na}_{2}$ EDTA increased $\mathrm{FeSO}_{4}$ absorption $3 \cdot 4$-fold $(P<0.001)$, whereas there was no increase in $\mathrm{Fe}$ absorption from ferric pyrophosphate. The lack of enhancing effect of $\mathrm{Na}_{2}$ EDTA on Fe absorption from ferric pyrophosphate is possibly related to the low solubility of this Fe compound in the gastrointestinal tract.

In situations where ascorbic acid is unstable during processing and storage, $\mathrm{Na}_{2}$ EDTA would appear to be a useful $\mathrm{Fe}$ absorption enhancer for addition together with soluble $\mathrm{Fe}$ compounds to inhibitory foods, or foods consumed in combination with inhibitory meals. Food products that could be considered for such fortification include beverages, milk, pasta, salt, sugar, soya sauce, fish sauce and cereal flours or weaning cereals that are stored for only short periods of time. However, in relation to $\mathrm{Fe}$ absorption, there would seem to be no advantage in adding $\mathrm{Na}_{2}$ EDTA plus a soluble Fe compound rather than adding $\mathrm{NaFeEDTA}$. $\mathrm{Na}_{2}$ EDTA plus $\mathrm{FeSO}_{4}$ may be less expensive, but NaFeEDTA may have the advantage of causing less sensory changes. For example, it is better to add NaFeEDTA to cereal flours or weaning cereals, since $\mathrm{FeSO}_{4}$ plus EDTA, like $\mathrm{FeSO}_{4}$ alone, has been shown to catalyse fat oxidation reactions during storage (Hurrell, 1997).

A possible fortification strategy in developing countries where diets are high in both Fe and phytic acid would be to fortify foods with $\mathrm{Na}_{2}$ EDTA alone. The EDTA moiety will combine with the native food $\mathrm{Fe}$ that enters the common $\mathrm{Fe}$ pool in the gastrointestinal tract, thereby preventing the formation of non-absorbable $\mathrm{Fe}$-phytate complexes and enhancing $\mathrm{Fe}$ absorption. This strategy would be less expensive and would avoid many of the sensory problems associated with the addition of Fe to foods.

$\mathrm{Na}_{2}$ EDTA would be a major aid to Fe-fortification programmes if it enhanced $\mathrm{Fe}$ absorption from poorlysoluble $\mathrm{Fe}$ compounds such as ferrous fumarate, ferric pyrophosphate and elemental $\mathrm{Fe}$. These compounds can often be added to foods when NaFeEDTA causes unacceptable sensory changes, or is considered too expensive. Although ferrous fumarate has a similar relative absorption to $\mathrm{FeSO}_{4}$, ferric pyrophosphate and elemental $\mathrm{Fe}$ are much less well absorbed. The addition of $\mathrm{Na}_{2}$ EDTA to foods fortified with these compounds could potentially increase $\mathrm{Fe}$ absorption to nutritionally-useful levels. Although in our studies we could show no benefit of $\mathrm{Na}_{2}$ EDTA on $\mathrm{Fe}$ absorption from wheat cereal fortified with ferric pyrophosphate, this radiolabelled compound was only $15 \%$ as well absorbed as $\mathrm{FeSO}_{4}$. This value is lower that the $21-74 \%$ relative absorption previously reported for ferric pyrophosphate in human studies (Hurrell, 1997) and it is still possible that other $\mathrm{Fe}$ compounds, such as ferrous fumarate, elemental $\mathrm{Fe}$ powders, or even different batches of ferric pyrophosphate, which are more readily dissolved in the common Fe pool in the gastrointestinal tract, will be enhanced in absorption by
$\mathrm{Na}_{2}$ EDTA in a similar way to the soluble Fe-fortification compounds.

EDTA is capable of binding stoichiometrically with virtually every metal in the periodic table (West \& Sykes, 1960). $\mathrm{Fe}^{3+}$ binds EDTA strongly at the $\mathrm{pH}$ of the stomach but, as the $\mathrm{pH}$ rises in the intestine, the bond weakens and EDTA complexes are formed with other metals (International Nutritional Anemia Consultative Group, 1993). Which metal complex is formed depends on the binding constant of the metal with EDTA, the $\mathrm{pH}$ and the EDTA:metal ion molar ratio (West \& Sykes, 1960). There is a concern that EDTA compounds added to foods may negatively influence the metabolism of other essential minerals, such as $\mathrm{Zn}, \mathrm{Ca}, \mathrm{Mg}$ and $\mathrm{Cu}$, or increase the absorption of potentially-toxic minerals such as $\mathrm{Mn}, \mathrm{Pb}$, $\mathrm{Hg}, \mathrm{Al}$ and $\mathrm{Cd}$. Studies with the nutritionally-important minerals indicate a positive influence of EDTA or no effect. NaFeEDTA has been shown to increase $\mathrm{Zn}$ absorption in rats and adult women, easily compensating for an increased urinary $\mathrm{Zn}$ excretion (Davidsson et al. 1994b; Hurrell et al. 1994), whereas NaFeEDTA-fortified bread rolls fed to women had no influence on Ca absorption or urinary excretion (Davidsson et al. 1994b). There are no human studies reporting the influence of EDTA compounds on $\mathrm{Mg}$ or $\mathrm{Cu}$ absorption. There are also virtually no studies on the influence of EDTA compounds on the absorption and metabolism of potentially-toxic minerals. Davidsson et al. (1998) showed that consumption of an NaFeEDTAfortified infant cereal by adults had no influence on Mn absorption and urinary excretion. However, there is still a need to evaluate the influence of EDTA compounds on the metabolism of $\mathrm{Pb}, \mathrm{Hg}, \mathrm{Cd}$ and $\mathrm{Al}$.

In summary, we have demonstrated that NaFeEDTA is a useful $\mathrm{Fe}$ fortificant for cereal-based foods. $\mathrm{Fe}$ absorption by human subjects was 2-4-fold greater from infant cereals or bread rolls fortified with NaFeEDTA than from the same foods fortified with either $\mathrm{FeSO}_{4}$ or ferrous fumarate. We have also demonstrated that $\mathrm{Na}_{2}$ EDTA will enhance the absorption of $\mathrm{FeSO}_{4}$ at EDTA:Fe molar ratios of 1:1 and below, indicating that $\mathrm{Na}_{2}$ EDTA can be used as an alternative to ascorbic acid to enhance the absorption of soluble Fe compounds as well as native food Fe. We could not demonstrate, however, that $\mathrm{Na}_{2}$ EDTA will enhance the absorption of insoluble Fe compounds such as ferric pyrophosphate.

\section{References}

Bothwell TH, Charlton RW, Cook JD \& Finch CA (1979) Iron Metabolism in Man, pp. 405-410. Oxford: Blackwell Scientific Publications.

Brown E, Hopper J Jr, Hodges JL Jr, Bradley B, Wennesland R \& Yamauchi H (1962) Red cell, plasma, and blood volume in healthy women measured by radiochromium cell-labelling and hematocrit. Journal of Clinical Investigation 41, 2188-2190.

Cook JD, Layrisse M, Martinez-Torres C, Monsen E \& Finch CA (1972) Food iron absorption measured by an extrinsic tag. Journal of Clinical Investigation 51, 805-815.

Cook JD, Reddy MB, Burri J, Juillerat MA \& Hurrell RF (1997) The influence of different cereal grains on iron absorption from infant cereal foods. American Journal of Clinical Nutrition $\mathbf{6 5}$, 964-969. 
Davidsson L, Almgren A \& Hurrell RF (1998) Sodium iron EDTA (NaFe(III)EDTA) as a food fortificant does not influence absorption and urinary excretion of manganese in healthy adults. Journal of Nutrition 128, 1139-1143.

Davidsson L, Galan P, Kastenmayer P, Cherouvrier F, Juillerat MA, Hercberg S \& Hurrell RF (1994a) Iron absorption in infants: The influence of phytic acid and ascorbic acid in formulas based on soy isolate. Pediatric Research 36, 816-822.

Davidsson L, Kastenmayer P \& Hurrell RF (1994b) Sodium iron EDTA (NaFe (III) EDTA) as a food fortificant. The effect on the absorption of zinc and calcium in women. American Journal of Clinical Nutrition 60, 231-237.

DeMaeyer E \& Adiels-Tegman M (1985) The prevalence of anaemia in the world. World Health Statistics Quarterly 38, 302-316.

Derman DP, Bothwell TH, Torrance JD, Bezwoda WR, MacPhail AP, Kew MC, Sayers MH, Disler PB \& Charlton RW (1980) Iron absorption from maize (Zea mays) and sorghum (Sorghum vulgare) beer. British Journal of Nutrition 43, 271-279.

Eakins JD \& Brown DA (1966) An improved method for the simultaneous determination of iron-55 and iron-59 in blood by liquid scintillation counting. International Journal of Applied Radiation and Isotopes 17, 391-397.

El-Guindi M, Lynch SR \& Cook JD (1988) Iron fortification from fortified flat breads. British Journal of Nutrition 59, 205-213.

Flowers CA, Kuizon M, Beard JL, Skikne BS, Covell AM \& Cook JD (1986) A serum ferritin assay for prevalence studies of iron deficiency. American Journal of Hematology 23, 141-151.

Forbes AL, Adams CE, Arnaud MJ, Chichester CO, Cook JD, Harrison BN, Hurrell RF, Kahn JG, Morris ER, Tanner JT \& Whittaker P (1989) Comparison of in vitro, animal and clinical determinations of iron bioavailability: International Nutritional Anemia Consultative Group Task Force report on iron bioavailability. American Journal of Clinical Nutrition 49, 225-238.

Hallberg L, Brune M \& Rossander L (1989) Iron absorption in man: ascorbic acid and dose-dependent inhibition by phytate. American Journal of Clinical Nutrition 49, 140-144.

Hallberg L, Rossander L \& Skanberg A-B (1987) Phytates and the inhibitory effect of bran on iron absorption in man. American Journal of Clinical Nutrition 45, 988-996.

Hercberg S, Galán P \& Dupin H (1987) Iron deficiency in Africa. World Review of Nutrition and Dietetics 54, 201-236.

Hosein F, Marsaglia G \& Finch CA (1967) Blood ferrokinetics in normal man. Journal of Clinical Investigation 46, 1-9.

Hurrell RF (1997) Preventing iron deficiency through food fortification. Nutrition Reviews 55, 210-222.

Hurrell RF, Furniss DE, Burri J, Whittaker P, Lynch SR \& Cook JD (1989) Iron fortification of infant cereals: a proposal for the use of ferrous fumarate or ferrous succinate. American Journal of Clinical Nutrition 49, 1274-1282.

Hurrell RF, Juillerat MA, Reddy MB, Lynch SR, Dassenko SA \& Cook JD (1992) Soy protein, phytate and iron absorption in man. American Journal of Clinical Nutrition 56, 573-578.

Hurrell RF, Reddy M \& Cook JD (1999) Inhibition of non-haem iron absorption in man by polyphenol-containing beverages. British Journal of Nutrition 81, 289-295.
Hurrell RF, Reddy MB, Dassenko SA, Cook JD \& Shepherd D (1991) Ferrous fumarate fortification of a chocolate drink powder. British Journal of Nutrition 65, 271-283.

Hurrell RF, Ribas S \& Davidsson L (1994) $\mathrm{NaFe}^{3+}$ EDTA as a food fortificant: influence on zinc, calcium and copper metabolism in the rat. British Journal of Nutrition 71, 85-93.

International Nutritional Anemia Consultative Group (1993) Iron EDTA for Food Fortification. Washington, DC: The Nutrition Foundation/ILSI.

Joint FAO/WHO Expert Committee on Food Additives (1999) Report of fifty-third meeting of the Joint FAO/WHO Expert Committee on Food Additives. Geneva: WHO.

Layrisse M, Chaves JF, Mendez-Castellano H, Bosch V, Tropper E, Bastardo B \& Gonzales E (1996) Early response to the impact of iron fortification in the Venezuelan population. American Journal of Clinical Nutrition 64, 903-907.

Layrisse M, Cook JD, Martinez-Torres C, Roche I, Kuhn N, Walker RB \& Finch CA (1969) Food iron absorption: A comparison of vegetable and animal foods. Blood 33, 430-443.

Layrisse M, Martinez-Torres C \& Gonzales M (1977) Fe III EDTA complex as iron fortification. American Journal of Clinical Nutrition 30, 1166-1174.

Lozoff B, Jiménez E \& Xolf AW (1991) Long term development outcome of infants with iron deficiency. New England Journal of Medicine 325, 687-694.

MacPhail AP, Bothwell TH, Torrance JD, Derman DP, Bezwoda WR \& Charlton RW (1981) Factors affecting the absorption of iron from Fe(III)EDTA. British Journal of Nutrition 45, 215-227.

MacPhail AP, Charlton R, Bothwell TH \& Bezwoda WR (1985) Experimental Fortificants. In Iron Fortification of Foods, pp. 55-75 [FM Clydesdale and KL Weimer, editors]. New York: Academic Press Research.

MacPhail AP, Patel RC, Bothwell TH \& Lamparelli RD (1994) EDTA and the absorption of iron from food. American Journal of Clinical Nutrition 59, 644-864.

Makover RU (1970) Extraction and determination of phytic acid in beans. Cereal Chemistry 47, 288-295.

Martinez-Torres C, Romano EL \& Layrisse M (1979) Fe III EDTA complex as iron fortification. Further studies. American Journal of Clinical Nutrition 32, 809-816.

Scrimshaw NS (1984) Functional consequences of iron deficiency in human populations. Journal of Nutritional Science and Vitaminology 30, 47-63.

Viteri FE, Garcia-Ibanez R \& Torun B (1978) Sodium iron EDTA as an iron fortification compound in Central America. Absorption studies. American Journal of Clinical Nutrition 32, 901-971.

Wennesland R, Brown E, Hopper J, Hodges JL Jr, Guttentag OE, Scott KG, Jucker IN \& Bradley B (1959) Red cell, plasma and blood volume in healthy men measured by radiochromium $\left(\mathrm{Cr}^{51}\right)$ cell tagging and hematocrit: influence of age, somatotype and habits of physical activity on variance after regression of volumes to height and weight combined. Journal of Clinical Investigation 38, 1065-1077.

West TS \& Sykes AS (1960) Diamino-ethane-tetra-acetic acid. In Analytical Applications of Diamino-Ethane-Tetra-Acetic Acid, pp. 9-22. Poole, Dorset: The British Drug Houses Ltd. 